\title{
EXPLORING THE OCCUPATIONAL SAFETY AND HEALTH COST TYPOLOGIES IN THE CONSTRUCTION OF MALAYSIAN URBAN RAIL INFRASTRUCTURE PROJECTS
}

\author{
Izatul Farrita Mohd KAMAR ${ }^{1}$, Asmalia Che AHMAD ${ }^{2}$, Mohmad Mohd \\ DERUS ${ }^{2}$, Nik Nur Khairunnisa Nik Mohd Ainul AZMAN ${ }^{2}$
}

DOI: 10.21163/GT_2019. 141.36

\begin{abstract}
:
Safety and health issues are very sensitive matters as they deal with human life. Unfortunately, the financial aspect of safety and health issues have been neglected as everybody wants safety, but nobody wants to pay a single cent for it. Work injuries create significant economic and humanitarian consequences to our society especially to the construction of urban rail infrastructure projects, where they involve billion of Malaysian Ringgit (RM). Understanding injuries and accident costs are necessary to an organisation when set up a budget on safety and health control. The objective of this paper is to review the literature on occupational safety and health typology costs for these projects. A review of the literature identified a set of components of safety and health cost typologies involved for the construction of these projects. The safety and health cost typologies comprise the 11 possible components for prevention, evaluation and monitoring costs, five components for direct costs of an accident, 16 for indirect costs of an accident and one component for an extraordinary cost. Underestimated cost of occupational safety and health could threaten the progress and overall project cost control and that affects the successful completion of these construction projects.
\end{abstract}

Key-words: Construction, Cost Typologies, Occupational Safety and Health, Urban Rail Infrastructure Project.

\section{INTRODUCTION}

The development of mega infrastructure project is significant category in Malaysia construction industry. This kind of project has been recognised as a high complexity project with numerous construction risks, large cost involvement, highly technical requirements and divers of resources. Mass Rapid Transit (MRT) and Light Rail Transport (LRT) are one of the development large urban rail infrastructure projects which need a large investment from public and private sector. The infrastructure sector receives the largest share of public sector development expenditure in every Malaysian Plan (Naidu, 2008). Moreover, the state-directed, privately operated approach that Malaysia adopted to spur economic growth has raised questions about the connection between government and business, and concerns about ethics and efficacy. The ETP, launched in 2010, attempts to break Malaysia out of the middle-income trap into the sphere of high-income countries by 2020 (Masrom et al., 2015) Differing from small and medium-sized construction projects in which routine practice can be applied; major infrastructure construction projects often involve a multitude of different

\footnotetext{
1 Universiti Teknologi MARA, Centre of Postgraduate Studies, Iskandar Campus, Seri Iskandar, 32610, Perak, Malaysia, izatu739@perak.uitm.edu.my

2 Universiti Teknologi MARA, Faculty of Architecture Planning and Surveying, Seri Iskandar Campus, Seri Iskandar, 32610, Perak, Malaysia,asmalia809@uitm.edu.my; moham266@uitm.edu.my; nickynisa93@yahoo.com
} 
tasks with a range of features (Shiferaw et al., 2012). They require more complicated organizational structures to deal with a number of elements in risk management. They need more structured organisational to deal a number of elements in risk management. For example, safety element is common element in large infrastructure projects. A lot of cases in large infrastructure projects for examples, delay and budget overruns due to unique site conditions (Kean, 2011), and hidden transaction costs (Sha, 2011). In addition, in huge construction projects, due to involvement of many workers, large and heavy plant, a lot of materials, complicated construction operations, multi-interface and complex management activities, so, the accident rate is much higher than the common construction projects (Guo et al., 2013).

Derived from the online newspapers, Table 1 reports the rate of fatalities at MRT construction workplace which occur every year since the project was started. Neither the worker's fatal nor nonfatal injuries, all of the accidents will create a significant economic burden to the stakeholders of the project.

Previous studies have shown that after the accident happened, a lot of losses have to be incurred by parties involved (Jallon et al., 2011; Goestsch, 2013; Asan \& Akasah, 2014; Pellicer et al., 2014; Feng et al., 2015; Stefanescu et al., 2018). These losses costs may include to victims, families, employers and society. In addition, it also affects construction company profit and loss statement due damages to productivity, property, equipment and morale. Moreover, the accident occurrence may also raise the cost and reduce contractors reputation and other losses as a result of delays in project completion. The costs that related with these accidents are both human (not directly measurable) and financial either to companies or society (sick leave, medical treatment and so on).

Based on the HSA (2006) resulted from accidents it can contribute to negative costs. There are lots negative costs and impacts resulted from accidents. In terms of financial costs to employers, the amounts were varied greatly from 0 to above $4.1 \times 10^{6} \$$. The average cost of the twelve middle-range accidents was nearly 57,000 $\$$. The costs were found in almost all cases underestimates, because productivity employers did not record losses. The accident costs from employers such as salary, staff replacement costs or overtime payments, production and productivity losses, retraining costs, personal injury claim compensation, repair bills, medical and travel expenses and increased supervision. However, salary costs take the largest costs category which nearly half (45\%) of the total losses costs.

In summary, accident costs are involving high costs for various parties and by preventing from accident occurrence can save more savings. Thus, preventing accident workplace also can make a good economic sense for contractors. So, the aim of this paper to investigate the components of occupational safety and health costs in construction projects. By identifying the specific costs, it will motivate the cost minimisation for firms to spend more investment in accident prevention as well as to boost more safety performance of construction projects.

\section{LITERATURE REVIEW}

The study of costs of accident was pioneered by Heinrich more than 80 years ago. There are many different terms for safety and health costs identified by other researchers. Since then, López-Alonso et al. (2013) clarified the cost related to safety and health in the workplace into three groups. 


\subsection{Safety cost}

Safety cost is distinguished between prevention, evaluation and monitoring costs. Prevention costs are costs to comply with legal requirements with respect to accident prevention, to implement measures to prevent accidents during construction work and to increase safety and health conditions in any work situation performed. The evaluation and monitoring costs, these are derived from the actions under company for appropriate testing and maintenance of safety and health measures adopted, according every works aspect that involved to reduce or minimise the accident risk or occupational disease.

Table 1. Accident cases at MRT construction site.

\begin{tabular}{llc}
\hline \multicolumn{1}{c}{ Year } & \multicolumn{1}{c}{ Accident Cases } & Sources \\
\hline 19 April 2014 & $\begin{array}{l}\text { Four workers injured at MRT site "Drill” at underground } \\
\text { station site along Jalan Cochrane. }\end{array}$ & Daniel (2014) \\
\hline 27 Jun 2014 & $\begin{array}{l}\text { Sub-contractor and staff sacked after metal slab falls on } \\
\text { car at the Pusat Bandar Damansara MRT construction site. }\end{array}$ & Brown (2014) \\
\hline 18 August 2014 & $\begin{array}{l}\text { Three MRT construction workers, are dead after being } \\
\text { trapped under a 300-tonne concrete span that collapsed at } \\
\text { the MRT worksite. }\end{array}$ & $\begin{array}{c}\text { Murad and Rodzi } \\
\text { (2014) }\end{array}$ \\
\hline 25 August 2014 & $\begin{array}{l}\text { Several precast concrete segments fell off a trailer onto a } \\
\text { road, causing traffic congestion near the Billion } \\
\text { roundabout flyovers along Jalan Cheras, Kuala Lumpur }\end{array}$ & $\begin{array}{c}\text { The Sraits Times } \\
\text { (2014) }\end{array}$ \\
\hline $\begin{array}{l}\text { 27 February } \\
\text { 2015 }\end{array}$ & $\begin{array}{l}\text { One worker killed, and another hurt in MRT construction } \\
\text { line's Semantan site. }\end{array}$ & Lin (2015) \\
\hline 24 May 2015 & $\begin{array}{l}\text { One worker dead when a temporary structure collapsed at } \\
\text { the Tun Razak Exchange (TRX) MRT underground } \\
\text { construction site. }\end{array}$ & Malaysia Kini (2015) \\
\hline
\end{tabular}

10 June 2015 Man plunges to death from MRT scaffolding in Jalan Duta.

Astro (2015)

Three workers from Bangladesh were killed at a Kota

31 August 2015 Damansara site, when 38m-long span weighing 650 tonnes was dislodged from a guideway under construction

Lin (2015) and fell to the ground below.

24 February One worker was killed after he was pinned down by steel 2016 while installing the ceiling at the Kwasa Damansara station construction site

The Malay Online (2016)

Two of the workers lost their legs in the accident

10 October 2017 while the other suffered injuries to his arms and legs after an explosion at a construction site in Bandar Malaysia

The Sun Daily (2017) South MRT site.

A Malaysian worker was killed while two of his co-

3 March 2018 workers were injured when a launching girder crane The Sun Daily (2018) collapsed at the Jinjang MRT construction site.

\subsection{Non-safety cost}

Non-safety cost is costs that not ensuring safety and health at work such as the company costs must meet following accidents and may due to breach of safety regulations. Non-safety costs can be divided into tangible and intangible accident costs. Tangible accident costs known as the costs associated with the accident occurrence at workplace, which can be estimated or calculated using traditional cost accounting methods. 
Meanwhile, intangible accident costs are immeasurable in economic terms or there are no performance indices to measure their organisation impact such as impaired company image, low worker morale, labour dispute or market loss (Gosselin, 2004).

\subsection{Other extraordinary cost}

This losses costs caused by events or situations that cannot be prevented or avoided either by technical or human resources available in construction works such as natural disaster. This costs items are out of the human scope and management control, and thus are named as uncontrollable costs. It cannot be added into a structured model which design to control costs regarding safety in the workplace.

The classification the costs as direct and indirect costs and concluded that indirect costs were significant as they accounted for as much as four times the direct costs of accidents. In contrast, proposed an alternative approach by dividing the costs into insured and uninsured costs. They criticized Heinrich's definition of indirect costs, arguing that many such costs, for example the overhead cost of insurance, were direct since they appeared in a firm's financial accounts. Although not all later researchers were persuaded to change their jargon to insured costs and uninsured costs, some of them were prompted to redefine the direct and indirect costs as insured and uninsured costs (Head and Harcourt, 1998). The categorization of accident costs into direct and indirect costs or insured and uninsured costs implies that focus only on the direct costs may fail to reveal the true losses to employers due to an accident. Many of the losses incurred by an accident were "hidden" and difficult to quantify (Lingard \& Rowlinson, 2005).

The Accident Cost Iceberg proposed by Bird (1974) showed that the proportion of hidden costs could be much larger than the costs directly related to the accident. Besides that, the indirect cost theory of workplace accidents developed by (Brody et al., 1990) suggested that the identification of indirect costs would motivate cost minimizing firms to increase investment in accident prevention to improve the safety performance of building projects. In addition to traditional classification of accident cost as direct (insured) and indirect (uninsured) costs, several researchers proposed different accident cost typologies based on the specific characteristics of the accident costs. For example, in the cost typology, safety and health costs are classified into three categories: insurance related costs; work related costs; and perturbation related costs. They are also classified as quantifiable, irreducible and intangible costs in this typology.

For the purpose of this research, the term that will be used is prevention, evaluation and monitoring costs, accident costs (direct costs), accident costs (indirect costs) and extraordinary costs. These terms are suitable to be used which are conjunction from the previous researchers and in line with the current practice on this field. Prevention, evaluation and monitoring costs are the budget that should be provided by the client and usually these costs are stated in the Contract Document. The direct costs are costs that incurred directly from the accident and tend to be associated with the injury treatment and any workers compensation as consequences of being injured. Typically, this cost can be claimed by the Social Security Organization (SOCSO) and insurance company and quite easy to calculate. However, the indirect cost can be more costly than direct costs because it is difficult to calculate. Besides that, all indirect costs items are not covered by the worker's compensation insurance and insurance company. However, there are lacks of studies for extraordinary costs (López-Alonso et al., 2013) because it is rarely happened, but the allocation for this cost is important as it may contribute huge financial losses especially to contractors. 


\section{RESEARCH METHODOLOGY}

Systematic literature search was conducted to collect data from empirical published research which includes scholarly articles published in peer-reviewed journals and conference proceedings, books, study reports, and trade publications. Based on contents, the following databases were searched to find potential literature sources: Web of Science, EBSCOHost, Emerald, Sage Journals, Science Direct, Scopus, Springer Link, Taylor and Francis, Wiley Online Library, Google scholar, existing safety cost model developed by Department of Safety and Health (DOSH) and safety bills of quantity by Public Works Department (PWD).

A pilot literature search was performed to evaluate the size of the literature which addresses the safety and health cost typologies from various occupational sectors. It was observed that the literature which addresses the various safety and health cost typologies is bulky and extensive. Furthermore, considerable portion of the literature investigates safety and health cost typologies in the construction sector, which specific for urban rail infrastructure project.

\section{DISCUSSIONS AND RESULTS}

Based on the literature review, a set of safety and health cost typologies in construction of urban rail infrastructure project was identified in order to understand the components of occupational safety and health costs. The safety and health cost typologies comprise of 11 possible components for prevention, evaluation and monitoring costs, five components for direct accident costs, the 16 components for indirect accident costs and only one component for extraordinary cost as listed in Table 2.

All of the cost typologies including the client's budget are required in a construction project. The safety and health cost items related to prevention, evaluation \& monitoring will be used for preventive costs in safety management and the budget allocated by the client should be enough. The direct and indirect accident costs will be insured by the company where the costs will be taken into account during the construction phase.

Although many studies show that the indirect accident costs are significant, there is no generally accepted ratio between direct and indirect costs of accidents. However, by considering certain amount allocated for indirect cost, the contractor can assume it as the contingencies items as well as to help them in estimating the cost if accident occurs at construction site.

On the other hand, few researches study on extraordinary cost; the cost losses caused by events that cannot be prevented by the human resource at site, or which are totally unavoidable, such as natural disasters. This cost category includes all of the items that are beyond the scope and control of management, and thus are classed as uncontrollable cost.

For the purpose of this research, these cost typologies are the most extensive view that will be used in the main study. However, the researcher will embed the additional item in the victim costs component, which is the ex gratia payment costs. The ex gratia payment costs are the amount of money that the contractor had to spend for the victim. These costs included the cost to send back victim's body to his country, the costs of escort staffs including their transportation, accommodation and all the expenses during their task and the ex gratia payment to the victim's family. 
Table 2. List and summary of previous occupational safety and health costs research.

\begin{tabular}{|c|c|c|c|}
\hline $\begin{array}{l}\text { Safety \& Health } \\
\text { Cost Typology }\end{array}$ & $\begin{array}{l}\text { Safety \& Health } \\
\text { Cost Component }\end{array}$ & Safety\& Health Cost Item & Author \\
\hline \multirow{22}{*}{$\begin{array}{l}\text { A) Prevention, } \\
\text { Evaluation \& } \\
\text { Monitoring } \\
\text { Costs }\end{array}$} & \multirow[b]{2}{*}{ 1) Insurance Costs } & Fixed insurance costs & \multirow[b]{2}{*}{$\begin{array}{l}\text { Feng et al. (2015); } \\
\text { Pellicer et an, } \\
\text { (2014); Riel and } \\
\text { Imbeau (1996); Teo } \\
\text { and Feng (2011); } \\
\begin{array}{l}\text { Waehrer et al. } \\
(2007)\end{array}\end{array}$} \\
\hline & & SOCSO & \\
\hline & \multirow{2}{*}{$\begin{array}{l}\text { 2)Prevention } \\
\text { Costs }\end{array}$} & Protection elements & \multirow{2}{*}{$\begin{array}{l}\text { Pellicer (2014); } \\
\text { López-Alonso et al. } \\
\text { (2013); JKR (2012) }\end{array}$} \\
\hline & & Safety training & \\
\hline & $\begin{array}{l}\text { 3)Evaluation and } \\
\text { Monitoring } \\
\text { Costs }\end{array}$ & $\begin{array}{l}\text { Salary-safety manager, safety } \\
\text { officer \& site safety supervisor }\end{array}$ & $\begin{array}{l}\text { López-Alonso et al. } \\
\text { (2013); JKR (2012) }\end{array}$ \\
\hline & $\begin{array}{l}\text { 4)Medical Check } \\
\text { Up Costs }\end{array}$ & $\begin{array}{l}\text { Conduct health fitness by } \\
\text { Medical Officer }\end{array}$ & JKR (2012) \\
\hline & \multirow{2}{*}{$\begin{array}{l}\text { 5)OSH } \\
\text { Management } \\
\text { Costs } \\
\end{array}$} & OSH Planning & \multirow[t]{2}{*}{ JKR (2012) } \\
\hline & & OSH Management & \\
\hline & \multirow{5}{*}{$\begin{array}{l}\text { 6)Safe Working } \\
\text { Area Costs }\end{array}$} & $\begin{array}{l}\text { Security hoarding, scaffolding, } \\
\text { working platform, safety } \\
\text { netting, catch platform } \\
\text { (demolition works) }\end{array}$ & \multirow[t]{5}{*}{ JKR (2012) } \\
\hline & & $\begin{array}{l}\text { Scaffolding design \& Working } \\
\text { Platform (Professional } \\
\text { Engineer Approval) }\end{array}$ & \\
\hline & & $\begin{array}{l}\text { Safety } \\
\text { barricades/fencing/railing/scree } \\
\mathrm{n} \text { /wire netting/toe board, } \\
\text { guardrails, temporary foot } \\
\text { walks }\end{array}$ & \\
\hline & & $\begin{array}{l}\text { Working area coordinate } \\
\text { (lifting operations, moving, } \\
\text { shifting) }\end{array}$ & \\
\hline & & $\begin{array}{l}\text { Prevent the breeding of } \\
\text { mosquitoes, houseflies, rats, } \\
\text { insects/dangerous animals }\end{array}$ & \\
\hline & \multirow{3}{*}{$\begin{array}{l}\text { 7)Special Work } \\
\text { Condition Costs }\end{array}$} & Confined spaces/tunnel & \multirow[t]{3}{*}{ JKR (2012) } \\
\hline & & Traffic management \& signage & \\
\hline & & $\begin{array}{l}\text { Excavation works\& demolition } \\
\text { works }\end{array}$ & \\
\hline & \multirow{3}{*}{$\begin{array}{l}\text { 8)Electrical Work } \\
\text { Costs }\end{array}$} & $\begin{array}{ll}\begin{array}{l}\text { Safety maintenance } \\
\text { maintenance report }\end{array} & \& \\
\end{array}$ & \multirow[t]{3}{*}{ JKR (2012) } \\
\hline & & Safety signage & \\
\hline & & $\begin{array}{l}\text { Inspection of all electrical tools } \\
\text { and equipment }\end{array}$ & \\
\hline & \multirow{3}{*}{$\begin{array}{l}\text { 9)Hazardous } \\
\text { Chemicals \& } \\
\text { materials Works } \\
\text { Costs }\end{array}$} & $\begin{array}{l}\text { Chemical and health risk } \\
\text { assessment }\end{array}$ & \multirow[t]{3}{*}{ JKR (2012) } \\
\hline & & Labelling and storage & \\
\hline & & Personal protective equipment & \\
\hline
\end{tabular}




\begin{tabular}{|c|c|c|c|}
\hline $\begin{array}{l}\text { Safety \& Health } \\
\text { Cost Typology }\end{array}$ & $\begin{array}{l}\text { Safety \& Health } \\
\text { Cost Component }\end{array}$ & Safety\& Health Cost Item & Author \\
\hline & & Waste disposal & \\
\hline & & Chemical safety signage & \\
\hline & & $\begin{array}{l}\text { Training, monitoring } \\
\text { exposure }\end{array}$ & \\
\hline & & Health surveillance & \\
\hline & 10)Plant Costs & Inspection records & \\
\hline & & Designated person & \\
\hline & & $\begin{array}{l}\text { Radio communication set for } \\
\text { signal man \& operator }\end{array}$ & \\
\hline & & $\begin{array}{l}\text { Statutory inspection } \\
\text { approval by authorities }\end{array}$ & \\
\hline & $\begin{array}{l}\text { 11)Accommodatio } \\
\text { n \& Amenities } \\
\text { Costs }\end{array}$ & $\begin{array}{l}\text { Provide and maintain of toilet, } \\
\text { temporary rest areas, adequate } \\
\text { lighting and water and pest } \\
\text { control treatment }\end{array}$ & \\
\hline \multirow[t]{16}{*}{$\begin{array}{l}\text { B) Accident Costs } \\
\text { (Direct Costs) }\end{array}$} & \multirow[b]{2}{*}{ 1) Medical Costs } & Medical treatment & \multirow{2}{*}{$\begin{array}{l}\text { Feng, Zhang and } \\
\text { Wu (2015); Riel and } \\
\text { Imbeau (1996); Teo } \\
\text { and Feng (2011); } \\
\text { Waehrer et al. } \\
(2007)\end{array}$} \\
\hline & & Treatment at site & \\
\hline & \multirow[b]{2}{*}{ 2) Hospital Costs } & Evacuation to hospital & \multirow{2}{*}{$\begin{array}{l}\text { Riel and Imbeau } \\
(1996) ; \text { Waehrer et } \\
\text { al. (2007) }\end{array}$} \\
\hline & & Hospitalization & \\
\hline & \multirow{7}{*}{$\begin{array}{l}\text { 3)Damage/Repair } \\
\text { Costs }\end{array}$} & $\begin{array}{l}\text { Machinery, material, } \\
\text { equipment, property damage }\end{array}$ & \multirow{7}{*}{$\begin{array}{l}\text { Riel and Imbeau } \\
(1996) ; \text { Waehrer et } \\
\text { al. (2007) }\end{array}$} \\
\hline & & Cleaning & \\
\hline & & Function recovery & \\
\hline & & First aid cost & \\
\hline & & Evacuation to hospital & \\
\hline & & Treatment at site & \\
\hline & & Medical equipment & \\
\hline & \multirow{3}{*}{$\begin{array}{l}\text { 4)Compensation } \\
\text { Costs }\end{array}$} & $\begin{array}{l}\text { Worker`s Compensation } \\
\text { Insurance }\end{array}$ & \multirow{3}{*}{$\begin{array}{l}\text { Riel and Imbeau } \\
(1996) ; \text { Teo and } \\
\text { Feng (2011); Feng } \\
\text { et al. (2015) }\end{array}$} \\
\hline & & $\begin{array}{l}\text { Employment Injury Scheme } \\
\text { (SOCSO) }\end{array}$ & \\
\hline & & $\begin{array}{l}\text { Invalidity Scheme Benefits } \\
\text { (SOCSO) }\end{array}$ & \\
\hline & \multirow{2}{*}{ 5) Fine Costs } & Fines by authority & \multirow{2}{*}{$\begin{array}{l}\text { Riel and Imbeau } \\
(1996)\end{array}$} \\
\hline & & Fines by court & \\
\hline \multirow{6}{*}{$\begin{array}{l}\text { C) Accident Costs } \\
\text { (Indirect Costs) }\end{array}$} & \multirow{3}{*}{$\begin{array}{l}\text { 1) External } \\
\text { Investigation } \\
\text { Costs }\end{array}$} & Hospital victim & \multirow{3}{*}{$\begin{array}{l}\text { KLIACS_JKKP } \\
\text { (2013); Jallon et al. } \\
\text { (2011); Sun et al. } \\
\text { (2006) }\end{array}$} \\
\hline & & Investigation team & \\
\hline & & Cost to response & \\
\hline & \multirow{3}{*}{ 2) Incident Costs } & Time to provide first aid & \multirow{3}{*}{$\begin{array}{l}\text { KLIACS_JKKP } \\
(2013)\end{array}$} \\
\hline & & $\begin{array}{l}\text { Time for transportation to } \\
\text { hospital/clinic/ home }\end{array}$ & \\
\hline & & Loss productivity of all & \\
\hline
\end{tabular}




\begin{tabular}{|c|c|c|c|}
\hline $\begin{array}{l}\text { Safety \& Health } \\
\text { Cost Typology }\end{array}$ & $\begin{array}{l}\text { Safety \& Health } \\
\text { Cost Component }\end{array}$ & Safety\& Health Cost Item & Author \\
\hline & & affected workers & \\
\hline & & $\begin{array}{l}\text { Loss productivity of all } \\
\text { affected workers }\end{array}$ & \\
\hline & \multirow{2}{*}{ 3) Accident Costs } & Accident report & \multirow{2}{*}{$\begin{array}{l}\text { Laufer (1987); Feng } \\
\text { et al. (2015); } \\
\text { Pellicer et al. } \\
\text { (2014); } \\
\text { KLIACS_JKKP } \\
\text { (2013); }\end{array}$} \\
\hline & & Time lost & \\
\hline & \multirow{2}{*}{$\begin{array}{l}\text { 4)Replacement } \\
\text { Costs }\end{array}$} & Hiring & \multirow{2}{*}{$\begin{array}{l}\text { Head and Harcourt } \\
\text { (1998); Jallon et al. } \\
\text { (2011) }\end{array}$} \\
\hline & & Training & \\
\hline & $\begin{array}{l}\text { 5) Legal and } \\
\text { Administration } \\
\text { Costs }\end{array}$ & $\begin{array}{l}\text { Administrative works } \\
\text { (Accident report) }\end{array}$ & $\begin{array}{l}\text { Feng et al. (2015); } \\
\text { Jallon et al. (2011); } \\
\text { Brody et al. (1990); } \\
\text { Sun et al. (2006) }\end{array}$ \\
\hline & 6) Schedule Costs & $\begin{array}{l}\text { Capacity loss, additional work } \\
\text { hours needed to replace injured } \\
\text { worker, time lost by injured } \\
\text { employee, time lost after } \\
\text { accident by co-worker (Giving } \\
\text { help, watching, discussing), } \\
\text { extra hours employed to } \\
\text { recover production-overtime. }\end{array}$ & $\begin{array}{l}\text { Head and Harcourt } \\
\text { (1998) }\end{array}$ \\
\hline & $\begin{array}{l}\text { 7) Work in } \\
\text { Progress Costs }\end{array}$ & $\begin{array}{l}\text { Cost of additional inventory, } \\
\text { cost of recovering work, cost } \\
\text { restoring safety and cost of } \\
\text { emergency responds. }\end{array}$ & \\
\hline & $\begin{array}{l}\text { 8) Productivity } \\
\text { Costs }\end{array}$ & $\begin{array}{l}\text { Capacity loss, additional work } \\
\text { hours needed to replace injured } \\
\text { worker, time lost by injured } \\
\text { employee, Extra hours } \\
\text { employed to recover } \\
\text { production-overtime. }\end{array}$ & $\begin{array}{l}\text { KLIACS_JKKP } \\
(2013) ; \text { Jallon et al. } \\
(2011) ; \quad \text { Brown } \\
\text { (2014); Brody et al. } \\
\text { (1990); Sun et al. } \\
\text { (2006); Oxenburgh } \\
\text { and Marlow (2005) }\end{array}$ \\
\hline & $\begin{array}{l}\text { 9) The Victim } \\
\text { Costs }\end{array}$ & $\begin{array}{l}\text { Temporarily salary for injured } \\
\text { worker, loss of job. }\end{array}$ & $\begin{array}{l}\text { KLIACS_JKKP } \\
(2013)\end{array}$ \\
\hline & $\begin{array}{l}\text { 10) Recruiting } \\
\text { Costs }\end{array}$ & $\begin{array}{l}\text { Advertising cost, cost for added } \\
\text { supervision of new or relocated } \\
\text { worker. }\end{array}$ & $\begin{array}{l}\text { KLIACS_JKKP } \\
(2013)\end{array}$ \\
\hline & $\begin{array}{l}\text { 11) Work Time } \\
\text { Costs }\end{array}$ & Cost of time taken & $\begin{array}{l}\text { KLIACS_JKKP } \\
\text { (2013) }\end{array}$ \\
\hline & 12) Capacity Lost & Slowdown in progress, stop & KLIACS_JKKP \\
\hline
\end{tabular}




\begin{tabular}{|c|c|c|c|}
\hline $\begin{array}{l}\text { Safety \& Health } \\
\text { Cost Typology }\end{array}$ & $\begin{array}{l}\text { Safety \& Health } \\
\text { Cost Component }\end{array}$ & Safety\& Health Cost Item & Author \\
\hline & Costs & work & $(2013)$ \\
\hline & $\begin{array}{l}\text { 13) Uninsured } \\
\text { Medical Costs }\end{array}$ & Uninsured medical costs & $\begin{array}{l}\text { Teo and Feng } \\
\text { (2011) }\end{array}$ \\
\hline & $\begin{array}{l}\text { 14) Management } \\
\text { Costs }\end{array}$ & $\begin{array}{l}\text { Time to assist accident } \\
\text { investigation }\end{array}$ & $\begin{array}{l}\text { KLIACS_JKKP } \\
(2013)\end{array}$ \\
\hline & $\begin{array}{l}\text { 15) Prevention } \\
\text { Costs }\end{array}$ & $\begin{array}{l}\text { Safety training for } \\
\text { additional/replacement worker }\end{array}$ & $\begin{array}{l}\text { KLIACS_JKKP } \\
\text { (2013) }\end{array}$ \\
\hline & $\begin{array}{l}\text { 16) Reputation } \\
\text { /Company } \\
\text { Image }\end{array}$ & Loss of market & Gosselin (2004) \\
\hline $\begin{array}{l}\text { D) Extraordinary } \\
\text { Costs }\end{array}$ & Natural disaster & Flood, Earthquake, etc. & $\begin{array}{l}\text { López-Alonso et al. } \\
\text { (2013) }\end{array}$ \\
\hline
\end{tabular}

\section{CONCLUSIONS}

Based on the review of related literatures, it can be summarised that the items for the components of prevention, evaluation \& monitoring of direct costs are insurance costs, prevention costs, evaluation \& monitoring costs, medical check-up costs, etc. The safety and health items for direct costs include medical costs, hospital costs, damage costs, compensation costs and fine costs which can be covered by insurance.

The insurance may uncover all items under indirect costs or uninsured costs such as incident costs, investigation cost, replacement and recruiting costs, legal and administrative costs and productivity costs are always involved when accidents happen. The typology or detailed safety costing items of construction projects is the first process in calculating the prevention costs.

The right accident costs in construction sites need knowledge, experience and systematic data management. If occupational safety and health costs are low, it could threaten the progress and overall project costs control. Hence, it can affect the successful completion of these construction projects.

\section{ACKNOWLEDGEMENTS}

The authors gratefully acknowledge the Centre of Postgraduate Studies, Universiti Teknologi MARA, Seri Iskandar Campus, Seri Iskandar for the support to this research study. The research study described in this paper is also supported by the Fundamental Research Grant Scheme (FRGS) under the Malaysian Ministry of Higher Education (MOHE). Project code: FRGS/1/2016/SSI11/UITM/03/1. We also owe the industrial practitioners a deep debt of gratitude for their kind cooperation and generous contributions to the development of this research. 


\section{R E F E R E N C E S}

Asan, A. \& Akasah, Z. A. (2014) Developing an Accident Causation Model for Accident Prevention at Building Construction Sites. International Civil and Infrastructure Engineering Conference, 28 September-1 October 2014, Kinabalu, Sabah, Malaysia.

Astro Awani (2015) Man Plunges to Death from MRT Scaffolding in Jalan Duta, http://english.astroawani.com/malaysia-news/man-plunges-death-mrt-scaffolding-jalan-duta$\underline{62043}$ [Accessed 21 May 2017]

Bird, F. E. (1974) Management Guide to Loss Control. Institute Press, Atlanta, https://trove.nla.gov.au/work/9646412?q\&versionId=11195552Brody, B., Létourneau, Y. and Poirier, A. (1990) An indirect cost theory of work accident prevention. Journal of Occupational Accidicents, 13 (4), 255-270.

Brown, V. (2014) Sub-Contractor and Staff Sacked after Metal Slab at MRT Construction Site Falls On Car, The Star Online, https://www.thestar.com.my/news/nation/2014/06/27/sub-contractorsacked-mrt-accident/ [Accessed 21 May 2017]

Daniel, S. (2014) Four workers injured at MRT site 'Drill', The Star Online, http://www.thestar.com.my/news/community/2014/04/19/four-injured-down-under-emergencydrill-at-construction-site-of-underground-mrt-station-meets-targ/ [Accessed 21 May 2017]

Feng,Y., Zhang, S. \& Wu, P. (2015) Factors influencing workplace accident costs of building projects. Safety of Science, 72: 97-104.

Goestsch, D. L. (2013) Construction Safety and Health, $2^{\text {th }}$ ed., Pearson Education, New Jersey, USA, $100-102$.

Gosselin, M. (2004) Analyse des avantages et des coûts de la santé et de la sécurité au travail en entreprise: Développement de l'outil d'analyse, IRSST, Quebec, 30-32.

Guo, H. L., Li, H. \& Li, V. (2013) VP-based safety management in large-scale construction projects: a conceptual framework. Automation in Construction, 34, 16-24.

Head, L. \& Harcourt, M. (1998) The direct and indirect costs of work injuries and diseases in New Zealand. Asia Pacific Journal of Human Resources, 36 (2), 466-474.

HSA (2006) Workplace Safety and Health Management. Dublin: Health and Safety Authority, Dublin, 27p.

Jallon, R., Imbeau, D. \& De Marcellis-Warin, N. (2011) development of an indirect-cost calculation model suitable for workplace use. Journal of Safety Research, 42, 149-164.

JKR. (2012) List of Quantities of Occupational Safety and Health Management. Malaysian Public Works Department, Malaysia. https://mafiadoc.com/senarai-kuantiti-pengurusan-keselamatandan-kesihatan-jkr_5a35b7a81723dd8cda00ea63.html [Accessed 22 March 2018]

Kean, J. R. (2011) improving project predictability with the application of critical project governance structures, Association Advancement of Cost Engineering (AACE) 2011, 2, 1023-1035

KLIACS_JKKP (2013) Study on accident costs at work for construction sector. http://oshacc.dosh.gov.my/ [Accessed 22 March 2018]

Laufer, A. (1987) Construction Accident Costs and Management Safety Motivation, Journal of Occupational Accidents, 8 (4), 295-315

Lin, M. M. (2015) One Worker Killed, Another Hurt in MRT Semantan Mishap. The Malay Mail Online, Retrieved 21 May 2017.

Lingard, H. \& Rowlinson, S. (2005), Occupational health and safety in construction project management. Spon Press, New York, 40-45.

López-Alonso, M., Ibarrondo-Dávila, M. P., Rubio-Gámez, M. C. \& Munoz, T. G. (2013) The impact of health and safety investment on construction company cost. Safety Science, 60, 151159. 
Malaysia Kini (2015) Worker Killed at TRX MRT Project Site, https://www.malaysiakini.com/news/299473 [Accessed 21 May 2017]

Masrom, M. A. N., Rahim, M. H. I. A., Mohamed, S., Chen, G. K. \& Yunus, R. (2015) Successful criteria for large infrastructure projects in Malaysia, Procedia Engineering, 125, 143-149.

Murad, D. \& Rodzi, N. H. (2014) 300-Tonne Concrete Span at MRT Construction Site Falls, Three Workers Feared Dead, The Star Online, https://www.thestar.com.my/news/nation/2014/08/18/mrt-beam-collapse-3-feared-dead/ [Accessed 21 May 2017]

Naidu, G. (2008) Chapter 7 Infrastructure Development in Malaysia. In Kumar, N. (ed.), International Infrastructure Development in East Asia-Towards Balanced Regional Development and Integration, ERIA Research Project Report 2007-2, Chiba: IDE-JETRO. 204227.

Oxenburgh, M. \& Marlow, P. (2005) The productivity assessment tool: computer-based cost benefit analysis model for the economic assessment of occupational health and safety interventions in the workplace. Journal of Safety Research, 36 (3), 209-214.

Pellicer, E., Carvajal, G. I., Rubio, M. C. \& Catalá, J. (2014) A method to estimate occupational health and safety costs in construction projects. KSCE Journal of Civil Engineering, 18 (7), $1955-1965$.

Riel. P. F. \& Imbeau, D. (1996) Justifying Investments in Industrial Ergonomics. International Journal of Industrial Ergonomics, 18 (5-6), 349-361.

Sha, K. (2011) Vertical governance of construction projects: an information cost perspective, Contruction management and Economics, 29 (11), 1137-1147.

Shiferaw, A. T., Klakegg, D. J. \& Haavaldsen, T. (2012) Governance of Public Investment Projects in Ethiopia. Project Management Journal, 43 (4), 52-69.

Stefanescu, L., Botezan, C. \& Craciun, L. (2018) Vulnerability analysis for two accident scenarios at an upper-tier seveso establishment in Romania. Geographia Technica, 13(1), 109-118.

Sun, L., Paez, O., Lee, D., Salem, S. \& Daraiseh, N. (2006), Estimating the Uninsured Costs of WorkRelated Accidents, Part 1: A Systematic Review. Theoretical Issues in Ergonomics Science, 7 (3), 227-245.

Teo, E. A. L. \& Feng, Y. (2011) Costs of construction accidents to singapore contractors. International Journal of Construction Management, 11 (3), 79-92.

The Malay Online (2016) MRT Worker Killed in Kwasa Damansara Station Construction Site Mishap, Retrieved 21 May 2017.

The Straits Times (2014) Another Accident Linked to Malaysia'S MRT Construction Causes 3-Hours Traffic Snarl in KL. Retrieved 21 May 2017.

The Sun Daily (2017) Three Foreign Workers Injured After Explosion Bandar Malaysia Updated [Accessed 22 March 2018]

The Sun Daily (2018) Jinjang MRT Gantry Collapse Kills M'sian Workers Injures 2 Others. [Accessed 22 March 2018]

Waehrer, G. M., Dong, X. S., Miller, Haile, T. E. \& Men, Y. (2007) Costs of occupational injuries in construction in the United States. Accident and Analysis Prevention, 39 (6), 1258-1266. 